\title{
Evaluation of Indigenous Solar Water Disinfection Reactor
}

\author{
Muhammad Saleem Muhammad \\ Department of Civil Engineering, Jubail University College, Jubail Industrial, Saudi Arabia
}

\begin{abstract}
Feasibility of enhancing the efficiency of solar disinfection units by utilizing an indigenous solar water disinfection reactor (SWDR), as an alternative and economical mean of disinfecting municipal water, has been studied. Several experiments were performed to investigate the effects of different control parameters on disinfection efficiency of SWDR including material type of containers, exposure time and water turbidity. Temperature of reactor base reached $62 \pm 1{ }^{\circ} \mathrm{C}$ within 2.5 hours corresponding to the ambient temperature of $28 \pm 1^{\circ} \mathrm{C}$. Water temperature in transparent polyethylene bag reached $55 \pm 1^{\circ} \mathrm{C}$ while colored polyethylene bag reached a minimum temperature of $46 \pm 1^{\circ} \mathrm{C}$ as compared to other tested container materials during the solar exposure of 2.5 hours. Various parameters such as water $\mathrm{pH}$, total Coliform, heterotrophic plate count (HPC) and viral indicator Coliphage were investigated before and after the experiment in order to test the water disinfecting efficiency of reactor. It was found that water having turbidity less than 23 NTU can be treated within 2.5 hours with $99.99 \%$ efficiency. However, utilizing SWDR one may get similar efficiency even water turbidity reached to $29.5 \mathrm{NTU}$ in similar environmental conditions. Results revealed that SWDR is more efficient and may be used to disinfect water in lesser time.
\end{abstract}

Keywords: Solar disinfection, Total Coliform, Coliphage, SWDR, Water turbidity.

\section{Introduction}

Beyond any shadow of doubt, clean and sterile water is scarce in developing countries and the goal of universal access to safe water and sanitation has not been achieved. A large portion of earth is covered with water but only $0.3 \%$ of fresh water is available. In fact the improper use of this fresh water is much more common than its proper use. Owing to these reasons, it becomes difficult task to supply clean drinking water to about 6.8 billion peoples in the world (Hunter et al., 2002). Limited access to safe water supply results in transmitting diseases such as diarrhea, hepatitis, giardiasis, dysentery and gastro intestinal with contaminated water among the people especially in the rural areas of the country where supplied water is polluted with variety of pathogen. It is reported that use of unsafe water cost life of around sixty thousand children every day worldwide (Tersieva and McFeters, 1991; Spears et al., 2006). Clean water is scarce and at least one third of the population in developing countries has no access to safe and reliable drinking water supplies (Saleem, 2009).

Water suspected to contain pathogens must be treated before its use to protect public health. Disinfection is a process used to eliminate pathogenic microorganisms. Different techniques are adopted by people to purify water including boiling, distillation, reverse osmosis, ozonation, GAC (Granular Activated Carbon), solar disinfection, chlorination, ion exchanger etc. Most of them are capital intensive and some techniques required sophisticated equipment, well skilled operator and burning of fossil fuels (Tersieva and McFeters, 1991; Spears et al., 2006). Solar disinfection technique is one of the cheapest 
and more economical methods for disinfection of water, utilizing solar radiation to inactivate and destroy pathogenic bacteria, water borne bacteria, viruses, and parasites and generally it is more useful in regions where other disinfection facilities are not accessible (Jamil et al., 2009). Solar disinfection method or SODIS as it is known is one of the simplest methods for providing acceptable quality of drinking water. Solar disinfection technique is the cheapest and simple enough to be applied by individuals or in households. It is more useful in those areas where accessibility for adopting alternatives methods is difficult (Wegelin et al., 1994; Wegelin and Sommer, 1998; Boyle et al., 2008). The World Health Organization considers SOLDIS to be valid option in those areas where no other means are available (Wegelin and Sommer, 1998). In Pakistan clean water supply is limited in the low income and rural areas. In some areas supply of portable water is available but unreliable due to addition of contaminants during transportation. Furthermore, the storage of this water may increase the chances of microbial growth and consequently water may require disinfection before use. Numerous health complains related to water borne pathogens are reported in the past (Saeed and Behzad, 2006; Qureshi et al., 2011)). Keeping in view the reality in future, supply of safe drinking water to all population seems to be impossible. One approach to provide safe water for all is household water treatment and safe storage, which is promoted globally by the WHO to reduce the global burden of waterborne diseases (WHO, 2012). Use of simple, economical and robust technique of solar disinfection may provide an alternative clean water supply at those sites.

Studies in the past showed successful application of solar disinfection process however, longer solar exposure time and low water turbidity is suggested (Ahmed and
Saleem, 2010; Faisal, 2010). Various solar reactor design had been tested for household disinfection of larger volume of drinking water and inactivation of entropathogen Cryptosporidium parvum were investigated however, longer time was required for achieving desired level of disinfection (GCouso et al., 2012). Research shows that Coliform-free potable waters are not necessarily pathogen-free because some viral pathogens may be present in the water (Ratto et al., 1989). Moreover, Coliphage is emerging as a global indicator microorganism for microbiological quality of drinking water (Hijnen, et al., 2006). The previous researchers showed that Coliphage assays are practical and although ratios of coliphages to those of other microorganisms tended to fluctuate, the Coliphage counts could give a useful estimate of numbers of the microorganisms in sewagepolluted water. (Wentsel, 1982; Grabow et al., 1984).

Based on a preliminary study carried out elsewhere a detailed investigation has been made by using an improved design of solar disinfection unit which provided promising results (Faisal, 2010). Main objective of the present study is to enhancing the efficiency of solar disinfection unit; which substantially kills the pathogens more efficiently. This objective can be achieved by using a simpler SWDR fabricated with indigenously available low cost material. Effect of solar radiation on standard water quality bacterial indicators (total coliform and HPC) will be also investigated along with viral pollution indicator Coliphage. In the literature researchers recommended that UV disinfection is not feasible to use for high turbidity waters which tend to reduce the efficiency of solar disinfection (Davies et al., 2009). As the presence of turbidity in water sample may hinder the solar disinfection process the effect of turbidity on solar water disinfection 
processes with and without reactor was also investigated (F-Ibáñez, 2009).

\section{Material and Methods}

A rectangular shape solar reactor was used as shown in Figure 1. Reactor was fabricated with bent aluminum sheet (semicircular) which concentrate the solar radiation to the focus point and top of the box was covered with removable glass which enhance greenhouse effect in the reactor. Sides of the reactor are made of wood (insulating material) which help in trapping the heat inside.

The solar water disinfection reactor works on the principle of greenhouse effect. The incoming solar radiation, after passing through the glass cover, is reflected by the aluminum sheet which concentrates the solar energy to the focus. This will rises the temperature of the water contained in the selected material more efficiently during disinfection process. As the solar radiation incident on aluminum sheet, the temperature of the base rises and it emits the thermal radiation which has a longer wavelength and thus thermal radiation is trapped inside the box.

The raw water was collected from a household tap and inoculated with domestic wastewater to obtain significant counts of microorganisms as shown in Table 1. Water samples each 1.5 liters were filled in six different containers namely; Poly Ethylene Terephthalate (PET) transparent and colored bottles, glass transparent and colored bottles, $6 \mathrm{~mm}$ gauge PET transparent and colored bags and placed separately inside the reactor and exposed to solar radiation at least up to 2.5 hours. Another set of samples kept outside the reactor to see the difference of disinfection with and without reactor. Samples were collected in the sterilized container at 30 minutes interval and promptly analyzed for various water quality parameters such as total coliform, HPC, Coliphage and $\mathrm{pH}$ as shown in table 1 .

The standard test for the coliform group was carried out by using the multiple tube fermentation technique and Spread Plate Count technique was used to determine the HPC as per the procedure mentioned in Standard Methods for the Examination of Water \& Wastewater (Clesceri et al., 2005). Analysis for Coliphage was done by following the procedure outlined in (Wentsel et al., 1982). A bench top $\mathrm{pH}$ meter manufactured by Thermo Orion (model 550A) was used for the determination of $\mathrm{pH}$. Analysis of samples was carried out at the Department of Environmental Engineering, NED University of Engineering \& Technology, Karachi, Pakistan.

Table 1. Analysis result of raw water for selected parameters.

\begin{tabular}{|l|l|l|}
\hline Parameters & Results & Units \\
\hline $\mathrm{pH}$ & $7.28 \pm 0.20$ & - \\
\hline Water Temperature & $28 \pm 1$ & ${ }^{\circ} \mathrm{C}$ \\
\hline Ambient Temperature & $28 \pm 1$ & ${ }^{\circ} \mathrm{C}$ \\
\hline Total Suspended Solid & $394 \pm 5$ & $\mathrm{mg} / \mathrm{L}$ \\
\hline Electrical Conductivity & $188 \pm 4$ & $\mu$-siemens/cm \\
\hline Color & Colorless & - \\
\hline Turbidity & $1.1 \pm 0.3$ & $\mathrm{NTU}$ \\
\hline Hardness & $123 \pm 5$ & $\mathrm{mg} / \mathrm{L}$ \\
\hline Chloride & $137 \pm 5$ & $\mathrm{mg} / \mathrm{L}$ \\
\hline Calcium & $56 \pm 06$ & $\mathrm{mg} / \mathrm{L}$ \\
\hline Magnesium & $29.2 \pm 0.8$ & $\mathrm{mg} / \mathrm{L}$ \\
\hline Sulfate & $71.3 \pm 0.2$ & $\mathrm{mg} / \mathrm{L}$ \\
\hline Res. Chlorine & $<0.2$ & $\mathrm{mg} / \mathrm{L}$ \\
\hline Sodium & $112 \pm 4$ & $\mathrm{mg} / \mathrm{L}$ \\
\hline Iron & $1.6 \pm 0.2$ & $\mathrm{mg} / \mathrm{L}$ \\
\hline Total Dissolved Solids & $372 \pm 5$ & $\mathrm{mg} / \mathrm{L}$ \\
\hline Total Suspended Solids & $394 \pm 5$ & $\mathrm{mg} / \mathrm{L}$ \\
\hline Total Coliform (MPN) & $7850 \pm 10$ & $\mathrm{MPN} / 100 \mathrm{ml}$ \\
\hline $\begin{array}{l}\text { Heterotrophic Plate } \\
\text { Count (HPC) }\end{array}$ & $83580 \pm 20$ & $\mathrm{PFU} / 100 \mathrm{ml}$ \\
\hline Coliphage & $32 \pm 1$ & $\mathrm{MPN} / 100 \mathrm{ml}$ \\
\hline & & \\
\hline
\end{tabular}

In other set of experiments effect of turbidity on solar water disinfection 
performance also investigated by adding turbidity in samples from 5 to 85 NTU using kaolin powder before exposing to solar radiation. Parallel runs were performed using SWDR.

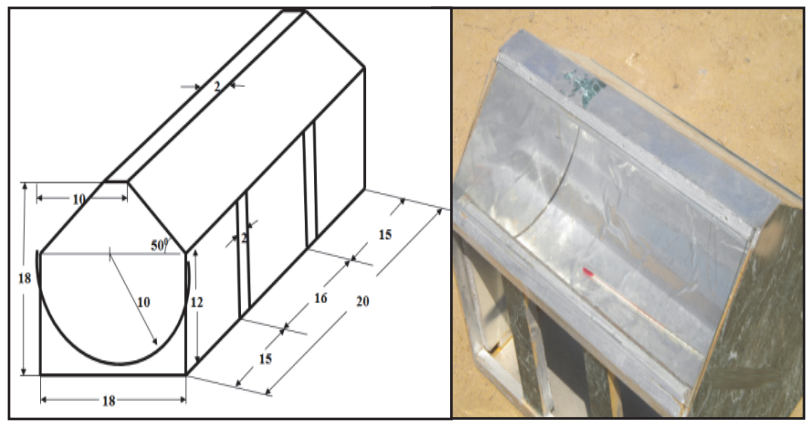

Fig. 1. Solar Water Disinfection Reactor (SWDR): a) dimensional sketch b) fabricated SWDR.

\section{Results and Discussion}

This section describes the results obtained during study before and after exposing to solar radiation. Effect of water turbidity on solar disinfection process with and without SWDR also elucidated

\section{Raw Water Characteristics}

In order to characterize the inoculated raw water, detailed physical, chemical and microbial analysis were performed and results of these analyses are presented in Table 1. Later water samples were filled in selected bags and bottles and exposed to sunlight with and without solar reactor.

\section{Temperature Measurement inside the Reactor}

During solar exposure of 2.5 hours, temperature variation inside the reactor was continuously monitored. Temperature of the base, longitudinal side and lateral side of the reactor were noted at 30 minutes interval using mercury thermometer results obtained are presented in figure 2 .

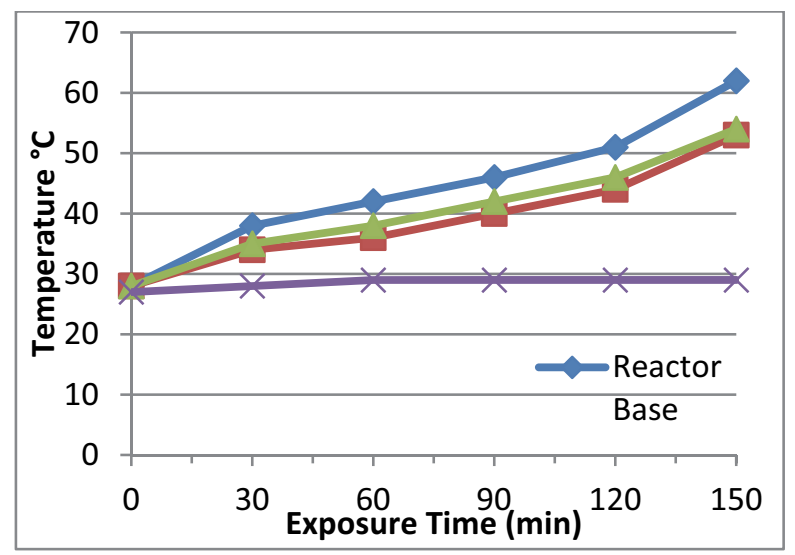

Fig. 2. Temporal variations in ambient, base and side walls temperature in the reactor during study period.

It can be seen from figure 2 that the base of the reactor attain high value of temperature up to $62^{\circ} \mathrm{C} \pm 1{ }^{\circ} \mathrm{C}$ whereas longitudinal side and lateral side reaches to $54^{\circ} \mathrm{C} \pm 1{ }^{\circ} \mathrm{C}$ and $53^{\circ} \mathrm{C} \pm$ $1^{\circ} \mathrm{C}$ respectively corresponding to time span of 150 minutes. The reactor base attains high temperature which may be due to direct incident of solar radiation on metal sheet having larger surface area.

\section{Water Temperature Variation:}

Temperature inside each bag and bottle were measured at 30 minutes interval using mercury thermometer. Water sample temperature was measured by three persons simultaneously as quickly as possible to minimize the loss of reactor temperature. Water temperature variation in different containers is presented in figure 3. Maximum water temperature of $55 \pm 1^{\circ} \mathrm{C}$ was achieved inside the transparent polyethene bag due to its thinner material. Minimum temperature of water $\left(46 \pm 1{ }^{\circ} \mathrm{C}\right)$ was found to be in colored glass bottles. Relatively high temperatures were observed in transparent material rather than in colored material due to the presence of color in the material which may obstruct some of the solar radiation to penetrate the bottle. Most of the researchers in the past used foiled backed reflector reactor to enhance the solar disinfection efficiency and reported that 
addition of either an absorptive or a reflective backing enhanced the reactor performance by achieving higher water temperature in shorter time span (A-Barcelo et al., 2013; Marques et al., 2013). Marques et al. was able to get the water temperature up to $50{ }^{\circ} \mathrm{C}$ in 3 hours exposure time. Similarly A-Barcelo et al. achieved water temperature of $39.8 \pm 3.8{ }^{\circ} \mathrm{C}$ in 4 hours exposure time.

Results show that the reactor used in current study provided higher temperature $\left(55 \pm 1^{\circ} \mathrm{C}\right)$ within 2.5 hour time span.

\section{Analysis of Samples with Constant Turbidity}

One set of samples having constant turbidity of 1.1 NTU was exposed to solar radiation. The results obtained for selected chemical and microbiological parameters are discussed in this section. As transparent containers showed significant gain in water temperature bacteriological parameters (TC and HPC) for only transparent containers are discussed below:

\section{pH}

It was found that $\mathrm{pH}$ of water samples remained almost unchanged in all experimental runs. The maximum change of 0.1 was noted (in transparent PET bottles) which may be due to the breaking and rejoining of $\mathrm{H}_{2} \mathrm{O}$ into $\mathrm{H}^{+}$and $\mathrm{OH}^{-}$ions but it hasn't the significant effect on disinfection process. Similar results were reported by some other researchers (Ahmed and Saleem, 2010).

\section{Total Coliform}

Temporal variation in the total Coliform counts during the study period is presented in figure 4. It is evident from figure 4 that the counts of TC decreases from 7850 $\mathrm{MPN} / 100 \mathrm{ml}$ to 0,12 and 130 in transparent shopping bag, transparent PET and transparent glass respectively during the exposure of 90 minutes. It shows that $\mathrm{TC}$ was quickly inactivated in transparent polyethene shopping bag within 30 minutes and reached to 0 $\mathrm{MPN} / 100 \mathrm{ml}$. However, TC reached to zero counts after exposure of 1.5 hours in all transparent containers.

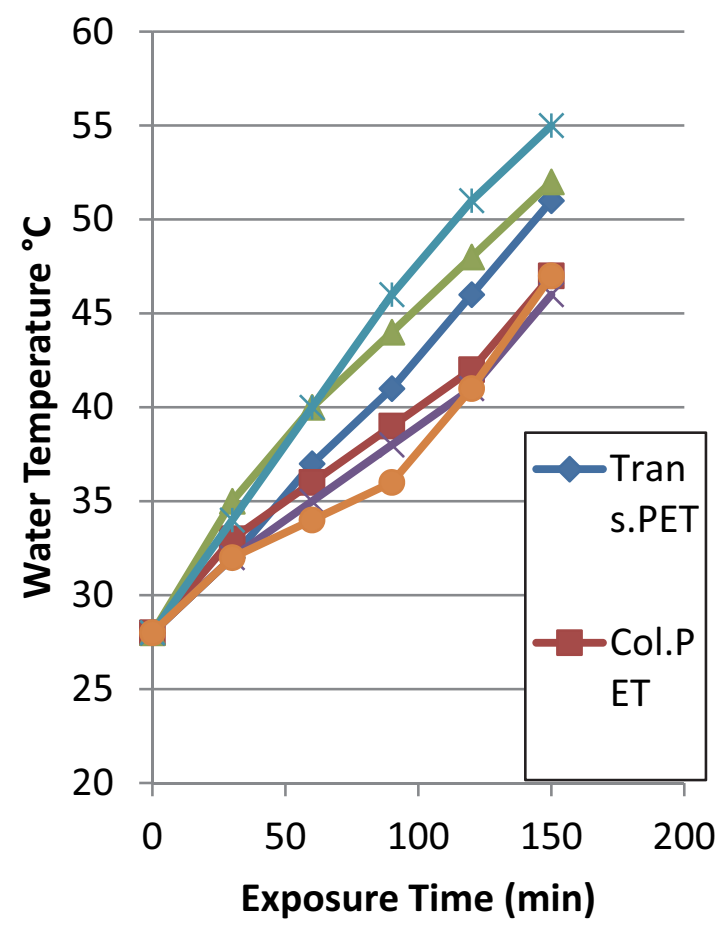

Fig. 3. Temporal water temperature variation in different containers.

In various solar disinfection studies researchers used indicator microorganism Escherichia coli to see the efficiency of the process. All of these studies have achieved different degrees of success (McLoughlin et al., 2004; Mani et al., 2006; Navntoft et al., 2008; Marques et al., 2013; A-Barcelo et al., 2013; Nalwanga et al., 2013). Total Coliform is a group of bacteria consist of various types of rod-shaped Gram-negative non-spore forming and motile bacteria. However, Escherichia coli is a less resistant member of TC group (Tersieva et al., 1991; Spears et al.,. 2006). In the present study one can easily assume that the inactivation of TC means that inactivation of Escherichia coli achieved at even lower exposure time. 


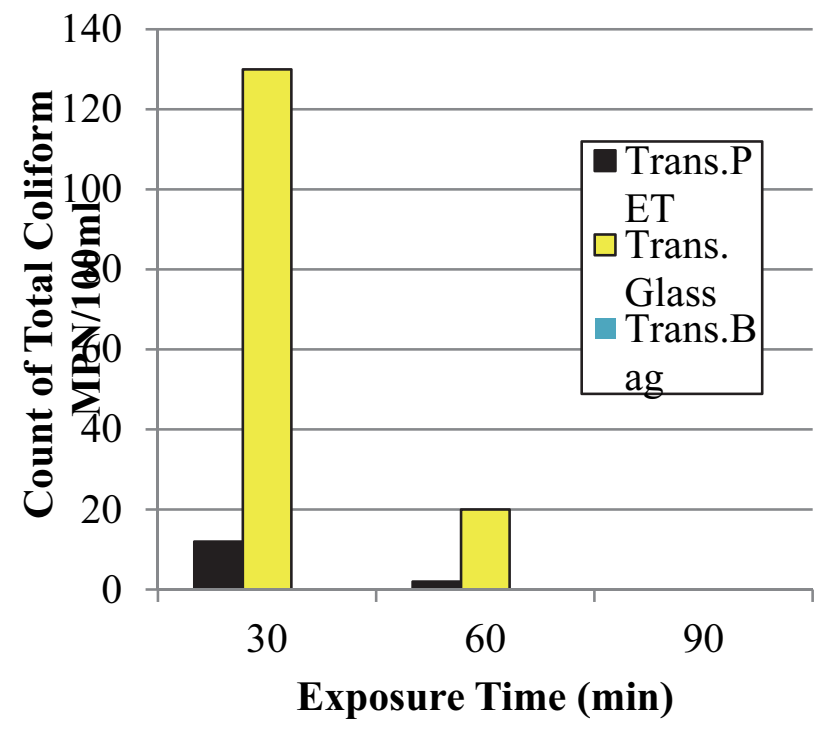

Fig. 4. Variation in TC with respect to time in various samples during study period.

\section{Heterotrophic Count Plate}

It is evident from figure 5 that there is reduction in HPC with exposure time however, it took longer time to inactivate as compared to TC. This may be attributed to the fact that HPC is the measure of all heterotrophic bacteria present naturally and consist of different strains of bacteria among which some may be more resistant as compared to TC. However HPC count reaches to almost zero count within 1.5 hour in transparent shopping bag then in transparent PET bottle within 2 hour. HPC remains present in the sample contained in colored containers even after the exposure of 3 hours.

\section{Coliphage}

Based on literature reviewed, Coliphage, as a viral indicator microorganism, testing was included to determine the microbiological water quality of drinking water. It can be seen from figure 6 that the removal of Coliphage virus in transparent bag is faster and reached to its minimum value to $0 \mathrm{MPN} / 100 \mathrm{ml}$ counts up to two hour of solar exposure. It is also evident from this figure that Coliphage has been completely destroyed within exposure of 2.5 hour in all transparent materials. However, solar disinfection plays an insignificant effect in the containers having colored materials. Delayed inactivation of virus as compared to TC and HPC may be attributed to their inherent resistance against solar radiation as compared to bacterial cell similar results are reported by Hijnen and coworkers in their study (Hijnen et al., 2006).

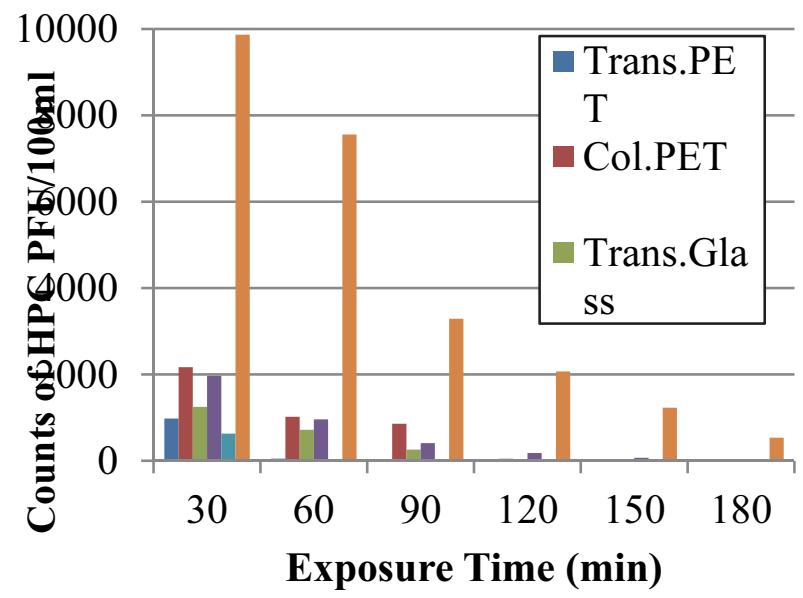

Fig. 5. Variation in TC with respect to time in different material.

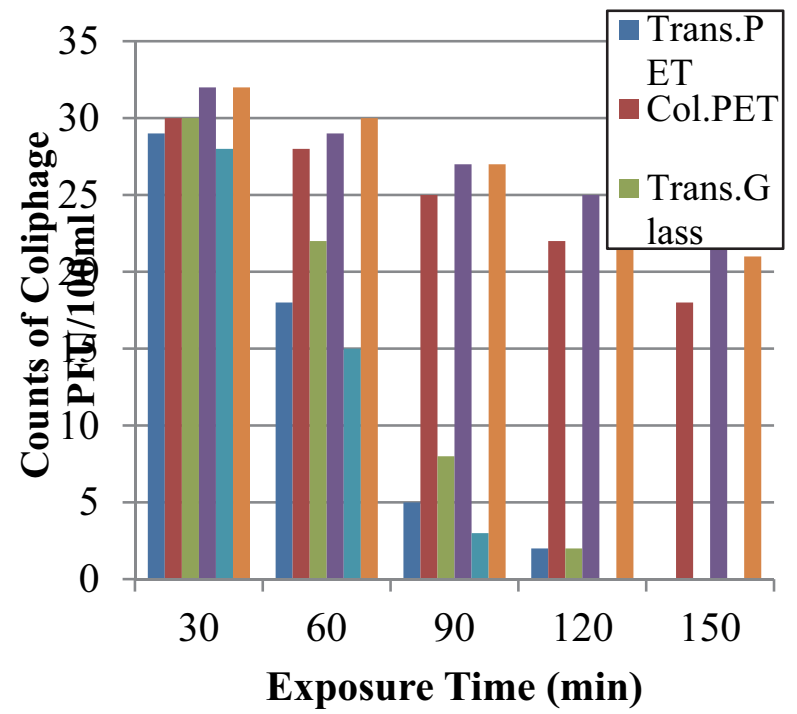

Fig. 6. Variation in Coliphage with respect to time in different containers. 


\section{Comparison of disinfecting efficiencies for SOLDIS process with and without SWDR}

In order to examine the change in efficiency of SOLDIS process due to SWDR the results obtained are also compared with those results which were carried out without using any solar reactor.

As previous results showed that solar disinfection process has significant effect on transparent material rather than in colored material, only results of transparent material including transparent polyethene bag, PET and glass bottles with and without reactor are compared with respect to removal percentage of total Coliform. Results based on constant turbidity (1.1 NTU) are presented in figure 7. Furthermore, the results obtained with variable turbidity effect on solar disinfection process with and without reactor also compared in figure 8 .

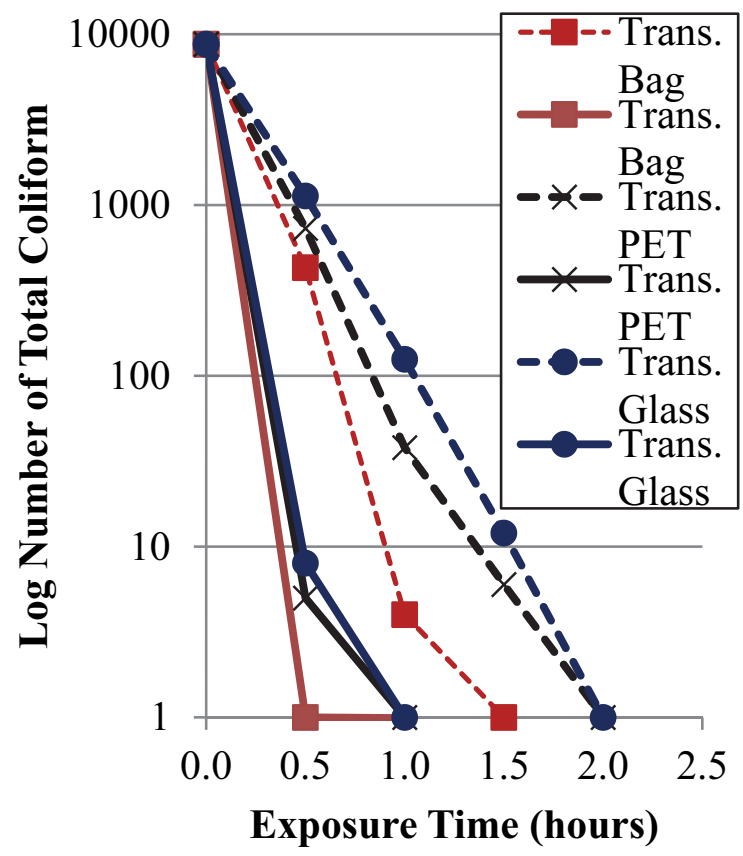

Fig. 7. Temporal variation in TC counts in transparent containers with and without SWDR.

\section{Comparison of disinfection efficiencies with constant turbidity}

It is evident from figure 7 that SWDR has given positive effect in boosting the efficiency of SOLDIS process. Total Coliform took almost 1.5 hour for complete inactivation when using SWDR while about 2 hour needed for their complete removal without using SWDR in transparent glass and PET bottles.

However, complete inactivation of total Coliform achieved within half an hour of solar exposure using SWDR whereas it takes about 1.5 hour without using reactor in transparent Polyethene bags. It is found that on the average about 50 to $75 \%$ lesser time is required to disinfect the water to same level of treatment while using SWDR.

\section{Effect of turbidity}

As turbidity is one of the important factors in disinfection process while using chemical as well as physical methods, effect of turbidity present in water samples also investigated. In this part of the study 15 raw water samples were prepared by adding kaolin powder giving turbidity from 5 NTU to 85 NTU. Each sample was exposed to solar radiation for one hour. Another set of duplicate samples were exposed to the solar radiation at the same time without using SWDR. A comparison of results obtained is presented in figure 8. Results show that a solar disinfection without reactor has disinfecting efficiency between $99.99 \%$ and $98 \%$ for samples having turbidity below 23 NTU. While using SWDR similar efficiencies can be achieved in samples having turbidity up to $29.5 \mathrm{NTU}$. Therefore, an improvement in disinfection efficiency is evident by using SWDR. Although the difference in turbidity is only $28.3 \%$ but turbidity is one of the issues in water treatment and need to be considered. Davies and colleagues recommended further detailed investigation to address the 
contribution of turbidity alone on the solar disinfection efficiency (Davies et al., 2009).

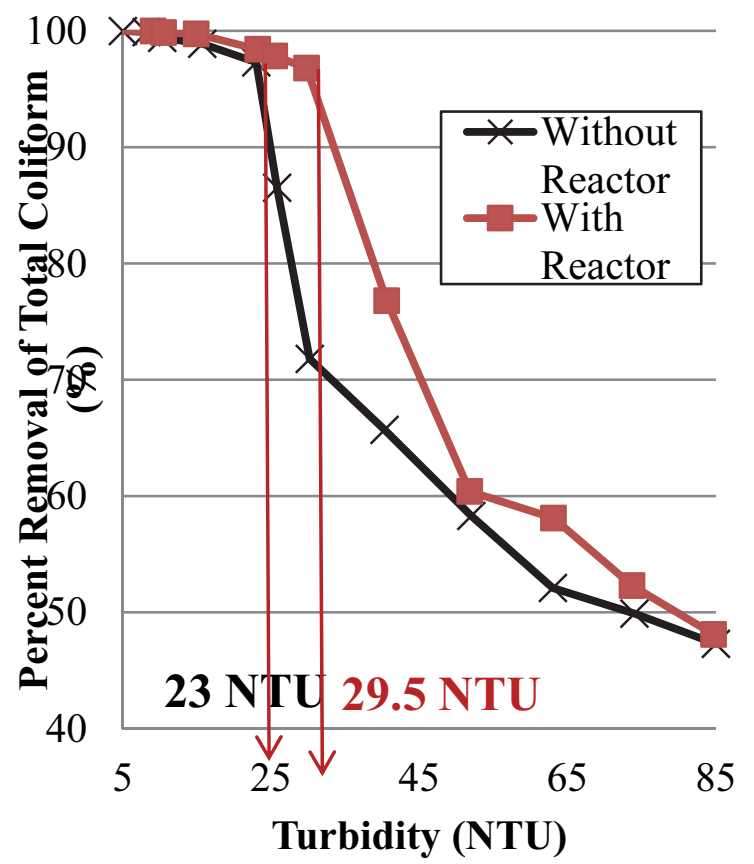

Fig. 8. Effect of water turbidity on the solar disinfection efficiency with and without SWDR.

\section{Conclusions and Recommendations}

Following specific conclusions derived based on the results obtained during this study:

1. SWDR made up of indigenous low cost material showed significant temperature rise (up to $62 \pm 1^{\circ} \mathrm{C}$ ) at the reactor base and enhanced the disinfection efficiency.

2. Transparent polyethene bag is found to be the best container for solar disinfection due to its thinner material and having large surface area for exposure to sunlight. Transparent PET and transparent glass come in the next order of priority followed by colored bottles and bags.

3. Solar disinfection has no significant effect on water $\mathrm{pH}$ and remained almost constant during all experimental runs

4. Complete inactivation of TC achieved in all transparent containers within two hours of exposure. Only 30 minutes are required to inactivate $\mathrm{TC}$ when using transparent polyethylene bag and making it a suitable container for solar disinfection.

5. Similar results obtained in case of HPC however, HPC required more time to reach value of zero which may be attributed to the fact that HPC is the measure of all heterotrophic bacteria present naturally and consist of different strains of bacteria among which some may be more resistant as compared to TC.

6. Coliphage as a viral indicator showed more resistance against solar radiation than bacterial indicators and its counts reached to zero in 2 hours of exposure in transparent polythene bags. However, counts reached to zero within 2.5 hours in case of all other transparent containers.

7. A comparison of solar disinfection experiments results with and without SWDR showed that about 50 to $75 \%$ lesser time is required to disinfect the water to same level of treatment while using SWDR.

8. Turbidity has negative effect on solar water disinfection efficiency. Only water samples having turbidity less than 23 NTU can be treated by solar disinfection method. However, samples having turbidity up to 29.5 NTU can be treated by using SWDR in similar environmental conditions.

\section{References}

Agulló-Barceló, M., Polo-López, M. I., Lucena, F., Jofre, J. and Fernández-Ibáñez, P. (2013) Solar advanced oxidation processes as disinfection tertiary treatments for real wastewater: Implications for water reclamation. Applied Catalysis B: Environmental, 136-137(0), 341350.

Ahmed, M.F. and Saleem, M. (2010) Disinfection of municipal water using solar radiation: an economical approach for rural dwellers in the coastal region of Karachi. Nucleus, 47(2), 165-171.

Boyle, M., C. Sichel, P. Ferna'ndez-Ibáñez, G. B. AriasQuiroz, M. Iriarte-Puña, A. Mercado, E. UbombaJaswa, and McGuigan, K. G. (2008) Bactericidal effect 
of solar water disinfection under real sunlight conditions. Appl. Environ Microbi. 78(10): 2997-3001.

Clesceri, L.S., A.E. Greenberg, and Eaton, A.D. (2005) Standard Methods for the Examination of Water \& Wastewater, 21st ed., American Public Health Association (APHA), American Water Works Association (AWWA) \& Water Environment Federation (WEF), USA.

Davies, C. M., Roser, D. J., Feitz, A. J., and Ashbolt, N. J. (2009) Solar radiation disinfection of drinking water at temperate latitudes: Inactivation rates for an optimized reactor configuration. Water Research, 43(3), 643-652.

Faisal, M. (2010) Fabrication and evaluation of low cost solar water disinfection reactor at KINPOE. MS Thesis, Karachi Institute of Power Engineering, Karachi.

Fernández-Ibáñez, P., C. Sichel, M.I. Polo-López, M. de Cara-García and J.C. Tello. (2009) Photocatalytic disinfection of natural well water contaminated by $<\mathrm{i}>$ Fusarium solani $</ \mathrm{i}>$ using $\mathrm{TiO}<\operatorname{sub}>2</$ sub $>$ slurry in solar CPC photo-reactors. Catalysis Today. 144(1): 62-68.

Gómez-Couso H, Fontán-Sainz M, Navntoft C, FernándezIbáñez P, and Ares-Mazás E. (2012) Comparison of different solar reactors for household disinfection of drinking water in developing countries: evaluation of their efficacy in relation to the waterborne enteropathogen Cryptosporidium parvum. Trans $R$ Soc Trop Med Hyg. 106(11):645-52. doi: 10.1016/j.trstmh.2012.07.014.

Grabow, W.O.K, P. Coubrough, E.M. Nupen, and B.W. Bateman (1984) Evaluation of Coliphages as indicators of the virological quality of sewage-polluted water. Water $S$ A. 10(1): 7-14.

Hijnen, W. A. M., E. F. Beerendonk, and Medema, G.J. (2006) Inactivation credit of UV radiation for viruses, bacteria and protozoan (oo) cysts in water: a review. Water Research. 40(1): 3-22.

Hunter, P. R., M. Waite, and Ronchi. E. (2002) Drinking water and infectious disease, Establishing the Links, CRC Press, London.

Jamil,Y., M.R. Ahmad, K. Ali, Habeeb, A. and Hassan, M. (2009) Use of solar energy for disinfection of polluted water. Soil \& Environ. 28(1): 13-16.

Mani, S. K., Kanjur, R., Bright Singh, I. S., and Reed, R. H. (2006) Comparative effectiveness of solar disinfection using small-scale batch reactors with reflective, absorptive and transmissive rear surfaces. Water Research, 40(4), 721-727.

Marques, A. R., Gomes, F. d. C. O., Fonseca, M. P. P., Parreira, J. S., and Santos, V. P. (2013) Efficiency of PET reactors in solar water disinfection for use in southeastern brazil. Solar Energy, 87(0), 158-167.

McLoughlin, O. A., Kehoe, S. C., McGuigan, K. G., Duffy, E. F., Touati, F. A., and Gernjak, W. (2004) Solar disinfection of contaminated water: A comparison of three small-scale reactors. Solar Energy, 77(5), 657-664.
Nalwanga, R., Quilty, B., Muyanja, C., Fernandez-Ibañez, P., and McGuigan, K. G. (2014) Evaluation of solar disinfection of E. coli under sub-saharan field conditions using a 25L borosilicate glass batch reactor fitted with a compound parabolic collector. Solar Energy, 100(0), 195202.

Navntoft, C., Ubomba-Jaswa, E., McGuigan, K. G., and Fernández-Ibáñez, P. (2008.) Effectiveness of solar disinfection using batch reactors with non-imaging aluminium reflectors under real conditions: Natural wellwater and solar light. Journal of Photochemistry and Photobiology B: Biology, 93(3), 155-161.

Qureshi, E.M.A., A.U. Khan and S. Vehra.(2011) .An investigation into the prevalence of water borne diseases in relation to microbial estimation of potable water in the community residing near River Ravi, Lahore, Pakistan. AJEST. 5(8): 595 - 607. DOI: 10.5897/AJEST11.001

Ratto, A., B. J. Dutka, C. Vega, C. Lopez, and El-Shaarawi, A. (1989) Potable water safety assessed by coliphage and bacterial tests. Water Research. 23(2): 253-255.

Saeed M, Behzad A. (2006) Stimulation of contaminant transport to Mitigate Environmental effects of wastewater in River Ravi. Pak. J. Water Resour., July - December, 10(2): 43 .

Saleem, M. (2009) Wastewater reuse potential in Pakistan: Guidelines for environment and public health protection. Int. J. of Environ Eng. 1(3): 306-320.

Spears, K. J., A. J. Roe, and Gally, D. L. (2006) A comparison of enteropathogenic and enterohaemorrhagic Escherichia coli pathogenesis. FEMS Microbiol. Lett., vol. 255: 187-202.

Tersieva, S. I. and McFeters. G. A. (1991) Survival and injury of E. coli, C. jejuni and Y. enterocolitica in stream water. Can. J. Microbiol., 37: 785-790.

Wegelin, M., and Sommer. B. (1998) Solar water disinfection (SODIS), destined for worldwide use. Waterlines magazine. 16(3): 30-32, 1998.

Wegelin, M., S. Canonica, K. Mechsner, T. Fleischmann, F. Pesaro, and Metzler. A. J. (1994) Solar water disinfection: Scope of the process and analysis of radiation experiments." Water Supply Res. Technol. Aqua. 43: 154160.

Wentsel, R. S., P. E. O'Neill, and Kitchens, J.F. (1982) Evaluation of Coliphage detection as a rapid indicator of water quality. Appl and Environ Microbi. 43(2): 430-434.

WHO, World Helth Organization, (2012) Consultation on the Development of a Strategy on Water Quality and Health http://www.who.int/water_sanitation_health/dwq/en/. 


\title{
تقييم مفاعل شمسي جديد لتطهير المياه
}

\author{
محمد سليم محمد \\ قسم العندسة المدنية، كلبة الجبيل الجامعبة، ددينة الجبيل الصناعية،

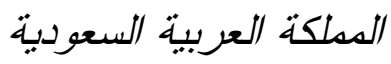

المستخلص. تمت دراسة جدوى تعزيز كفاءة التعقيم الثمسي من خلال الاستفادة من مفاعل تطهير اليباه بالطاقة الثمسية (SWDR) باعنبارها المتوسط البديل والاقتصادي لتعقيم اليلياه المحلية. حيث أجريت

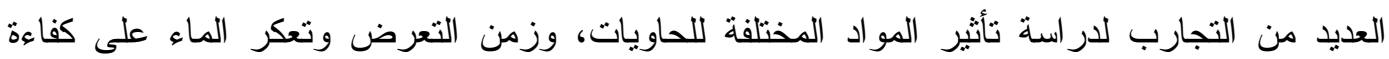

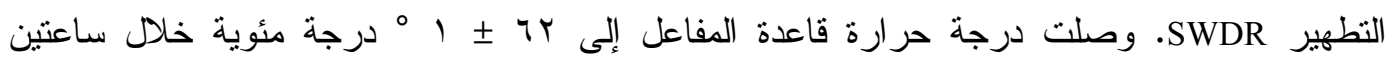

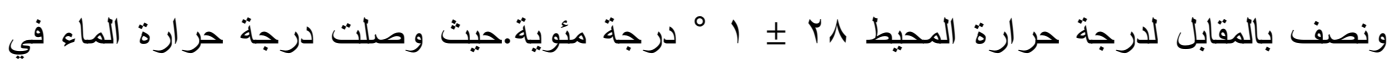

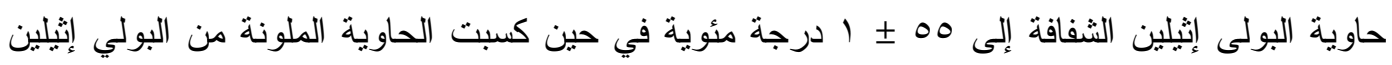

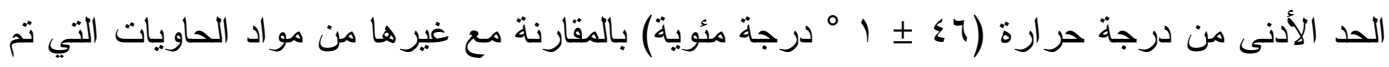
اختبارها من خلال التعرض الثمسي لساعتين ونصف. وقد تم النحقيق من المعايير المختلفة منل الرقم

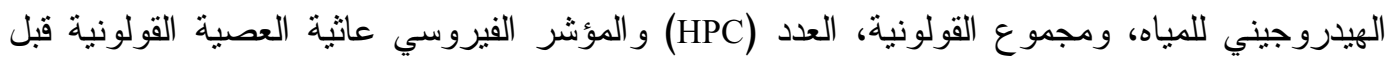

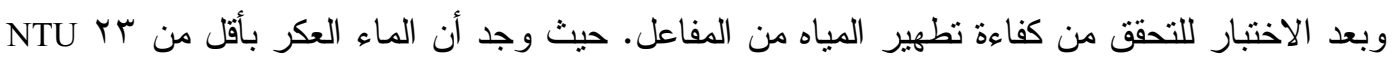

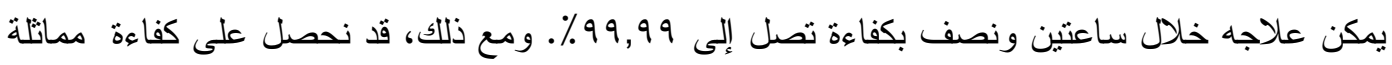

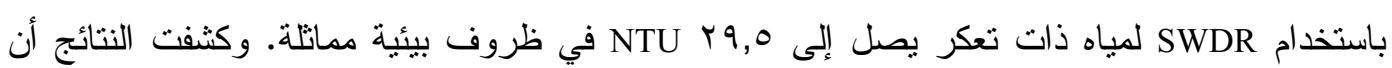
SWDR هو أكثر كفاءة، ويمكن استخدامه لنطهير المياه في وقت أقل. الكلمات الدفتاحية: تطهير شمسي, الكوليفورم الكلية, الكوليفيج, تعكر . اليباه. 